UDC 621.9.004.12

Doi: 10.31772/2587-6066-2018-19-4-613-621

For citation: Frolova E. A., Ivakin Ya. A., Smirnov A. O. [Method of quality anomalies detection in interactive electronic technical manuals for aircraft maintenance and repair]. Siberian Journal of Science and Technology. 2018, Vol. 19, No. 4, P. 613-621. Doi: 10.31772/2587-6066-2018-19-4-613-621

Для цитирования: Фролова Е. А., Ивакин Я. А., Смирнов А. О. Метод выявления аномалий качества интерактивных электронных технических руководств по эксплуатации и ремонту авиационной техники // Сибирский журнал науки и технологий. 2018. Т. 19, № 4. С. 613-621. Doi: 10.31772/2587-6066-2018-19-4-613-621

\title{
METHOD OF QUALITY ANOMALIES DETECTION IN INTERACTIVE ELECTRONIC TECHNICAL MANUALS FOR AIRCRAFT MAINTENANCE AND REPAIR
}

\author{
E. A. Frolova*, Ya. A. Ivakin, A. O. Smirnov
}

Saint Petersburg State University of Aerospace Instrumentation

67, Bolshaya Morskaya Str., Saint Petersburg, 190000, Russian Federation

*E-mail: frolovaelena@mail.ru

The purpose of developing a method for detecting quality anomalies of interactive electronic technical manuals (IETM) in application to aircraft maintenance and repair is an objective, purposeful interpretation of assessment of the specified quality. This method is a combination of the corresponding logical-mathematical model of such anomalies designed for subject content logic circuits (SCLC), and the algorithm of its performance in the technological process of compiling interactive electronic manuals.

The IETM model of quality anomalies provides the analysis of the SCLC structure as some basic graph and regards the anomaly as a more specific graph. The specific graph is a graphical description of various partial distortions of the logic presented in the form of SCLC. Such a representation of quality anomaly of IETM for aircraft maintenance and repair - by a graph isomorphically nested in the structure of its SCLC - allows to reduce the detection of such anomalies to the mathematico-algorithmic problem of detection or search for the corresponding isomorphic subgraph in the configuration of the corresponding logic circuit. This allows to detect persistable structural embeddings characterizing logical errors in the feeding of electronic content to IETM for aircraft maintenance and repair from the list $/$ database of predetermined anomalous logic substructures.

The proposed method for detecting IETM quality anomalies in application to aircraft maintenance and repair is both a methodological toolkit and an extensive basis for design of suitable software models for automatic procedures of valid structure and content correction in concrete interactive electronic technical manuals.

Keywords: interactive electronic technical manuals, aircraft, graph, quality anomalies.

\section{МЕТОД ВЫЯВЛЕНИЯ АНОМАЛИЙ КАЧЕСТВА ИНТЕРАКТИВНЫХ ЭЛЕКТРОННЫХ ТЕХНИЧЕСКИХ РУКОВОДСТВ ПО ЭКСПЛУАТАЦИИ И РЕМОНТУ АВИАЦИОННОЙ ТЕХНИКИ}

\author{
Е. А. Фролова*, Я. А. Ивакин, А. О. Смирнов \\ Санкт-Петербургский государственный университет аэрокосмического приборостроения \\ Российская Федерация, 190000, г. Санкт-Петербург, ул. Большая Морская, 67 \\ *E-mail: frolovaelena@mail.ru
}

Целью разработки метода выявления аномалий качества интерактивных электронных технических руководств (ИЭТР) по эксплуатации и ремонту авиационной техники является предметная ичеленаправленная интерпретация результатов оценки указанного качества. Данный метод представляет собой совокупность соответствующей логико-математической модели таких аномалий, разработанной применительно к логическим схемам предметного контента (ЛСПК), и алгоритма её применения в рамках технологического процесса создания интерактивных электронных руководств.

Модель аномалии качества ИЭТР предусматривает рассмотрение структуры ЛСПК как некоторого базового графа, а аномалии - как более частного графа. Такой более частный граф представляет собой графическое описание различных частных искажений логики, описываемой в виде ЛСПК. Такая репрезентация аномалии качества ИЭТР по эксплуатации и ремонту авиационной техники графом, изоморфно вложенным в структуру его ЛСПК, позволяет свести выявление указанных аномалий к математико-алгоритмической задаче распознавания или поиска соответствующего изоморфного подграфа в структуре соответствующей логической 
схемы. Это позволяет обнаружить и распознать устойчивые структурные вложения, характеризующче логические ошибки подачи электронного контента в ИЭТР по эксплуатации и ремонту авиационной техники из перечня (базы) заранее определённых аномальных логических подструктур.

Предлагаемый метод выявления аномалий качества ИЭТР по эксплуатации и ремонту авиаџионной техники представляет собой как методологический инструментарий, так и мощзую базу для создания соответствуюших образцов программных решений по автоматизации процедур корректной корректировки структуры и контент-наполнения рассматриваемых интерактивных электронных технических руководств.

Ключевые слова: интерактивные электронные технические руководства, авиационная техника, граф, аномалии качества.

Introduction. The purpose of quality assessment of IETM for aviation technology is to come to a general conclusion on the obtained degree of meeting the demands for interactive electronic technical manuals within the context of unclear initial expert data used for evaluation [1-5]. Assessment of quality of IETM for aircraft maintenance and repair means stating their compliance with the requirements of the already existing database of that quality indications.

The proposed method of detecting quality anomalies of the IETM in question is a combination of corresponding logical-mathematical model of such anomalies, developed for application to the subject content logic circuits (SCLC) [6; 7] and the algorithm of its performance in the technological process of designing interactive electronic manuals.

Anomaly representation by a graph isomorphically nested in SCLC configuration of IETM. The scientific and methodological concept of quality management of IETM for aircraft maintenance and repair implies that quality improvement of software technology for the specific electronic manuals is achieved by applying available qualimetric toolkits for software and information products $[8 ; 9]$. Particular attention is paid to quality improvement of IETM content, the factual material describing the subject area of maintenance and repair of specific aircraft models [10-12]. In turn, the SCLC method that provides the sufficient quality level for IETM design offers the developers a means specially focused on IETM for aircraft maintenance and repair content quality [13]. However, designing electronic content for IETM with the use of SCLC does not guarantee the absence of its quality anomalies. If the method of multi-level quality assessment of IETM for aircraft shows a low level of quality achieved in the design process, it will be necessary to improve this quality. Thus, there appears the problem of anomalies detection in the electronic content of the evaluated IETM. It is for solving this problem that the method of quality anomalies detection of IETM for aircraft maintenance and repair is aimed at. These IETM were originally developed on the basis of the corresponding SCLC.

The model of quality anomalies of IETM provides the analysis of the SCLC configuration as some basic graph and regards the anomaly as a more specific graph [13]. The specific graph is a graphical description of various partial distortions of the logic presented in the form of SCLC.

There is quite a number of typical logic distortions in the design of IETM electronic content, in the sequence of frame appearance, etc. The most common examples are logical ring, transitive closure, non-specified fact (condition execution failure). In other words, the SCLS structure is regarded as a basic graph, within which a subgraph isomorphic to the given one is determined. Here graph isomorphism is understood as equivalence ratio for a set of graphs $[14 ; 15]$. The graph, to which the subgraph within the basic graph that displays SCLC configuration relates as isomorphic, graphically specifies the corresponding type of content logical anomaly in IETM for aircraft maintenance and repair (anomalies of the logic of subject content representation as regards the SCLC).

The process of representation of the anomaly in the form of a graph isomorphically nested in the configuration of SCLC of IETM (when the description of the specified anomaly model is formalized by applying mathematical methods of the graph theory technique) takes the form shown in fig. 1. Strictly speaking, the algorithm for detection of an anomaly graph isomorphically embedded in SCLC of IETM, as related to the general method of detecting quality anomalies in IETM for aircraft maintenance and repair, will not undergo significant logical and structural changes. The algorithm initially specifies SCLC decomposition procedures and methods detecting embedded anomalous structures (based on the graph theory technique). The complexity of this approach is due to the fact that the task of quality anomalies detection in SCLC of IETM is regarded here as a problem of graph isomorphic nesting detection (or isomorphism to a subgraph); the existing algorithms of solving the problem reflect exponential time complexity of software implementation [15].

The problem of graph isomorphism detection has a correct interpretation in the subject area of designing IETM for aircraft maintenance and repair. In particular, there exists a set of effective algorithms for detection within a complex graph, such as SCLC configuration in a real, operational IETM for aircraft maintenance and repair, a subgraph isomorphic to the specified one (subgraph-quality anomaly) [15]. There are 2 classes of algorithms for such detection. Class 1 is the implementation of hierarchy principle for the so-called non-exhaustive algorithms that recursively improve their performance in the way of scope and precision of the parameter analysis of vertices and / or edges invariant to graph isomorphism, and, accordingly, called invariants. Class 2 of the algorithms relates to implementation of the same algorithm hierarchy principle, but in the way of exhaustion at one of the search steps of the so-called isomorphic permutation. The worst parameters are demonstrated by algorithms implementing the so-called total direct exhaustion. They can be applied only to SCLC of limited scale. At the same time, the solution of the problem of isomorphic nesting of subgraph into SCLC graph of IETM for aircraft maintenance and repair is trivial in regard to software tools and is described in $[14 ; 15]$. 
Thus, the representation of IETM for aircraft maintenance and repair quality anomaly by a graph isomorphically nested in the configuration of its SCLC allows to reduce detection of the specified anomalies to the mathematico-algorithmic problem of detecting the specified isomorphic subgraph in the corresponding logic scheme. Then it becomes possible to detect typical structural embeddings that characterize logic errors in the feeding of electronic content to IETM for aircraft maintenance and repair from the list / database of predetermined anomalous logic substructures.

Concretization of the graph model of IETM quality anomaly developed on the basis of logic schemes of the subject content. Analysis of presentation of IETM content quality anomalies as an isomorphic embedding of a graph reflecting the corresponding SCLC configuration showed that the graphs defining these anomalies may have a diverse and complex form.

The classification of mathematical methods for detecting graph isomorphism, i.e. methods for solving the problem of detection of a graph isomorphic to a specified one, is shown in fig. 2 [15]. As the choice of graph fragments of the same type is varied, the invariants are divided into three classes: local, quasi-global and global.

The solution of the subtask of invariant detection is carried out on the basis of the statement proved by the graph theory - graph $G$ is isomorphically embedded into graph $G^{\prime}$ if and only if $\varphi\left(G<G^{\prime}\right) \geq|G|[14]$.

Concretization of IETM quality anomaly graph model developed on the basis of SCLC involves determining the best mathematical method for solving the problem of isomorphic graph nesting that conforms to constraints of the subject area of IETM for aircraft maintenance and repair quality management.
Algorithm for detecting isomorphic nesting of a quality anomaly graph in SCLC configuration of IETM. The algorithm for solving the problem of detection of isomorphic graph nesting that conforms to constraints of the subject area of IETM for aircraft maintenance and repair quality management, as stated in the classification of methods given above, is implemented on the basis of compound method of directed exhaustion. It combines the main advantages offered by directed exhaustion methods that employ local, quasi-global and global invariants. The suggested algorithm makes use of the following invariants:

- number of vertices $n(L)$;

- number of edges $m(L)$;

- power vector $S(L)=\left(s_{1}, s_{2}, \ldots, s_{n}\right)$, which, in particular, yields numerical invariants $s(L)=\min S(L, x)$ and $s^{\prime}(L)=\max S(L, x)$;

- outdegree $S(x)$

- indegree $S^{+}(x)$;

- adjacency matrix $A(L)$.

In the design of the algorithm the following assumptions and limitations were adopted:

- it is assumed that the vertices (edges) of the graphs have the same properties, i. e. in the algorithm weighting factors of the vertices (edges) are neglected. The reason is that for different types of graphs there will be different requirements for weighting factors;

- all vertices should be numbered;

- only directed graphs are considered: when analyzing undirected graphs, it is necessary to specify one edge as two, i. e. as connecting vertices in both directions;

- "unconnected" vertices are not considered, i. e. each object must have at least one link with another object.

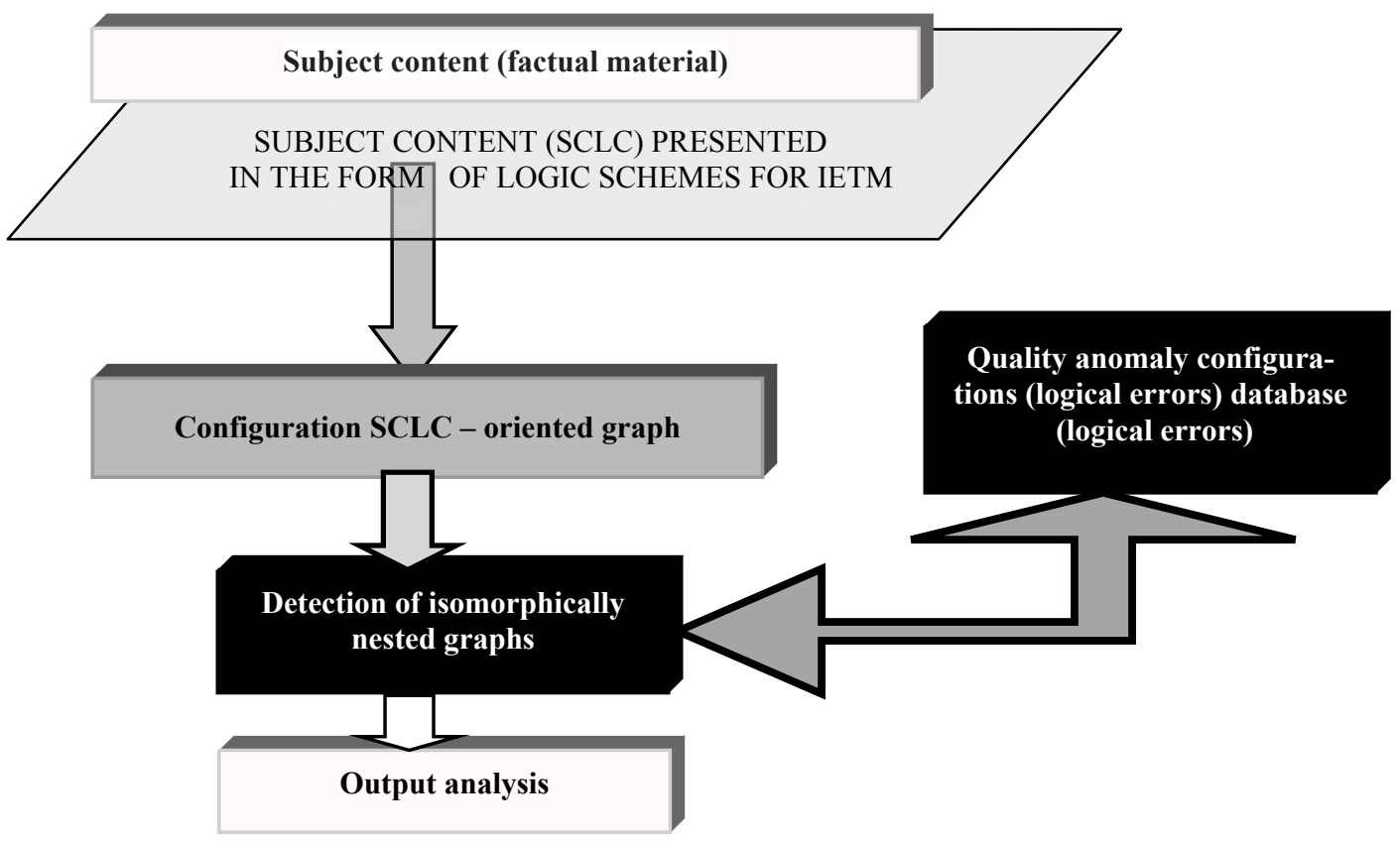

Fig. 1. Key steps of anomaly representation by a graph isomorphically nested in SCLC configuration of IETM

Рис. 1. Основные этапы представления аномалии графом, изоморфно вложенным в структуру ЛСПК ИЭТР 


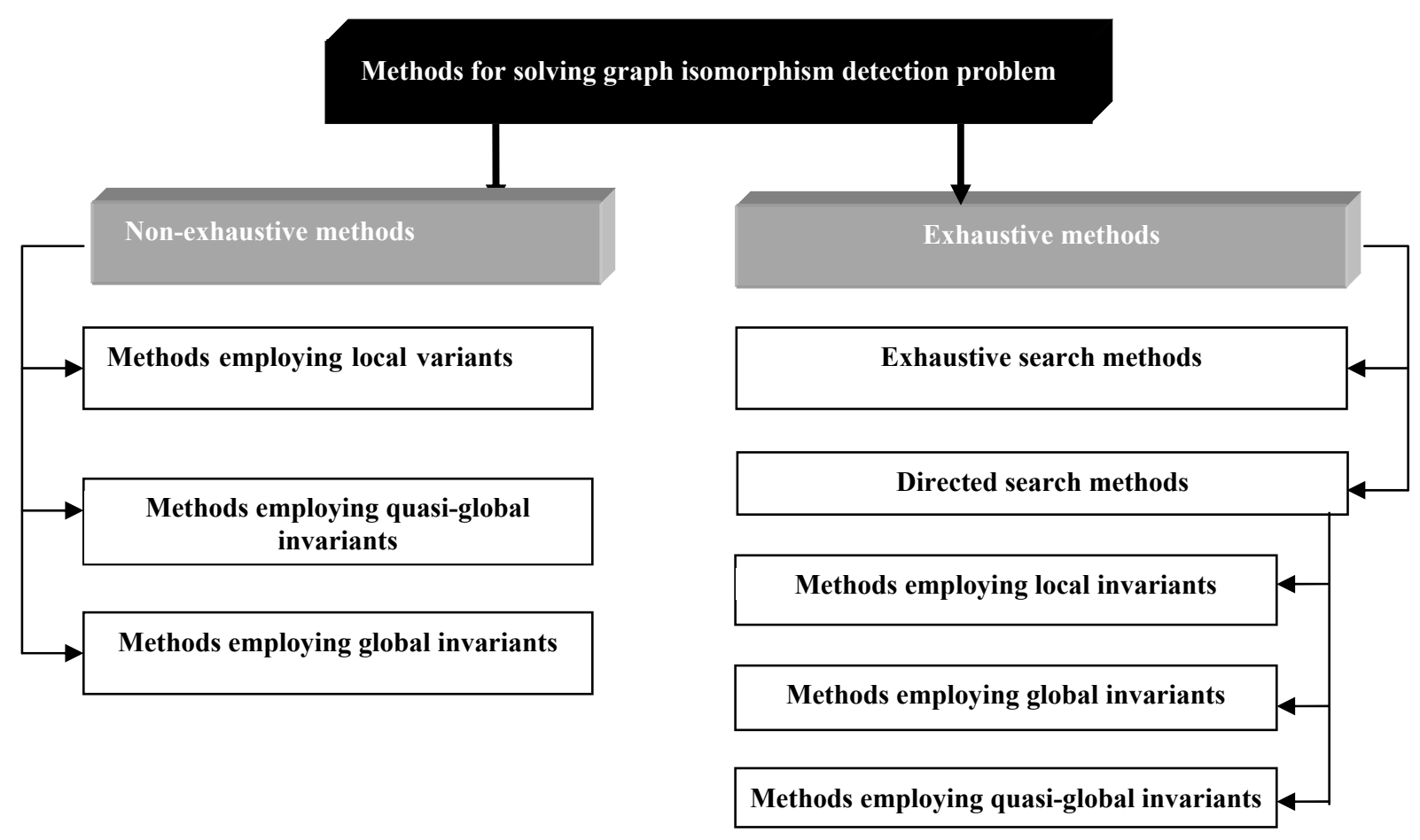

Fig. 2. Classification of graph isomorphism detection methods

Рис. 2. Классификации методов установления изоморфизма графов

The methodological basis of the proposed algorithm for solving the problem of isomorphic graph nesting is the thesis that logic circuits $S_{1}=\left\{A_{1}, R_{1}\right\}$ and $S_{2}=\left\{A_{2}, R_{2}\right\}$ in combination outline a constraints system that affects a set of hypothetically possible solutions and significantly reduces it. Here it is not an exhaustion of solution variants, which would lead to $N$-factorial searches, but application of a constraints system by a specific algorithm onto a specially devised field; inside this field, as a result of a sequence of actions aimed at meeting the requirements of the constraints system, a ready-made solution is formed. This variant may look like a permutation matrix for graphs of the same dimension. What can be assumed is as follows: a field with a set of hypothetically possible permutations can be presented in the form of $n \times m$ matrix; for $n$ and $m$ - the number of graph vertices, respectively. Such a matrix should be correctly called further as possible permutations matrix. So, as an illustrative example, in fig. 3 there are two graphs $-G_{1}$ and $G_{2}$, and the corresponding adjacency matrices. The subgraph of $G_{1}$ isomorphic to $G_{2}$ is highlighted in gray. Permutation matrix for $G_{2}$ graph and the subgraph of $G_{1}$ isomorphic to $G_{2}$ is shown in fig. 4. Still, the invariant of isomorphic permutation remains the same:

$$
\varphi=\left(\begin{array}{llllllllll}
1 & 2 & 3 & 4 & 5 & 6 & 7 & 8 & 9 & A \\
1 & 7 & 8 & 4 & 5 & A & 2 & 3 & 6 & 9
\end{array}\right) .
$$

The essence of the algorithm suggested for detection of isomorphic nesting of a quality anomaly graph in SCLC configuration of IETM can be adequately presented by solving a problem of an isomorphic nesting of graphs as shown in fig. 4. Adjacency matrices and possible permutations matrices for this pair of graphs are shown in fig. 5. In the matrix of possible permutations $C$, in the first column, there is an enumeration of all graph $B$ vertices, and in the first string - of all graph $A$ vertices. The number of possible permutations is entered in $N+1$ column.

The initial completion of a matrix of possible permutations is carried out by analyzing indegrees and outdegrees of the original graphs according to the rule: vertex can $B_{i}$ correspond to vertex $A_{j}$ only if indegrees and outdegrees of this vertex are greater than or equal to those of vertex $A_{j}$. Thus, the initial filtering of solution variants is performed. Mathematically, this is formalized and written as:

$$
C_{i j}=\left\{\begin{array}{c}
1, \text { if } s\left(B, b_{i}\right) \leq s\left(A, a_{i}\right) \text { and } s\left(B, b_{j}\right) \leq s\left(A, a_{j}\right), \\
0, \quad \text { in other variants. }
\end{array}\right.
$$

Further adjustment of the matrix is performed by imposing the following system of constraints:

1. Graphs cannot be isomorphic if there is at least one null string in "Number of possible permutations" column.

2. In case of one-to-one correspondence of vertices $B_{i}$ and $A_{j}\left(B_{i} \leftrightarrow A_{j}\right)$, there can be no other symbols ' 1 ' in column $j$ of possible permutations matrix $(C)$. To meet this restrictive condition, it is necessary to eliminate from column $j$ of the matrix the so-called "extra" characters ' 1 '. As the stated correspondence may turn out false for a certain vortex, the elimination of characters ' 1 ' from the ma- 
trix must be performed so that a possibility to restore the matrix at a certain step still remained. The Mirage variable is introduced for this purpose: its value changes after each cycle of imposing a constraints system on the possible permutations matrix. Consequently, the operations to be made can mathematically be represented as follows: if
$C[N+1, i]=1$ and $C[j, i]={ }^{\prime} 1$ ', the element $C[k, i]$ of value ' 1 ' (for $k=1 \ldots m ; k \neq i$ ) is assigned the current value of Mirage variable. If all the values of the matrix column "number of possible permutations" are greater than 1 , to find a quick solution, it is necessary to start work at the lowest value string.
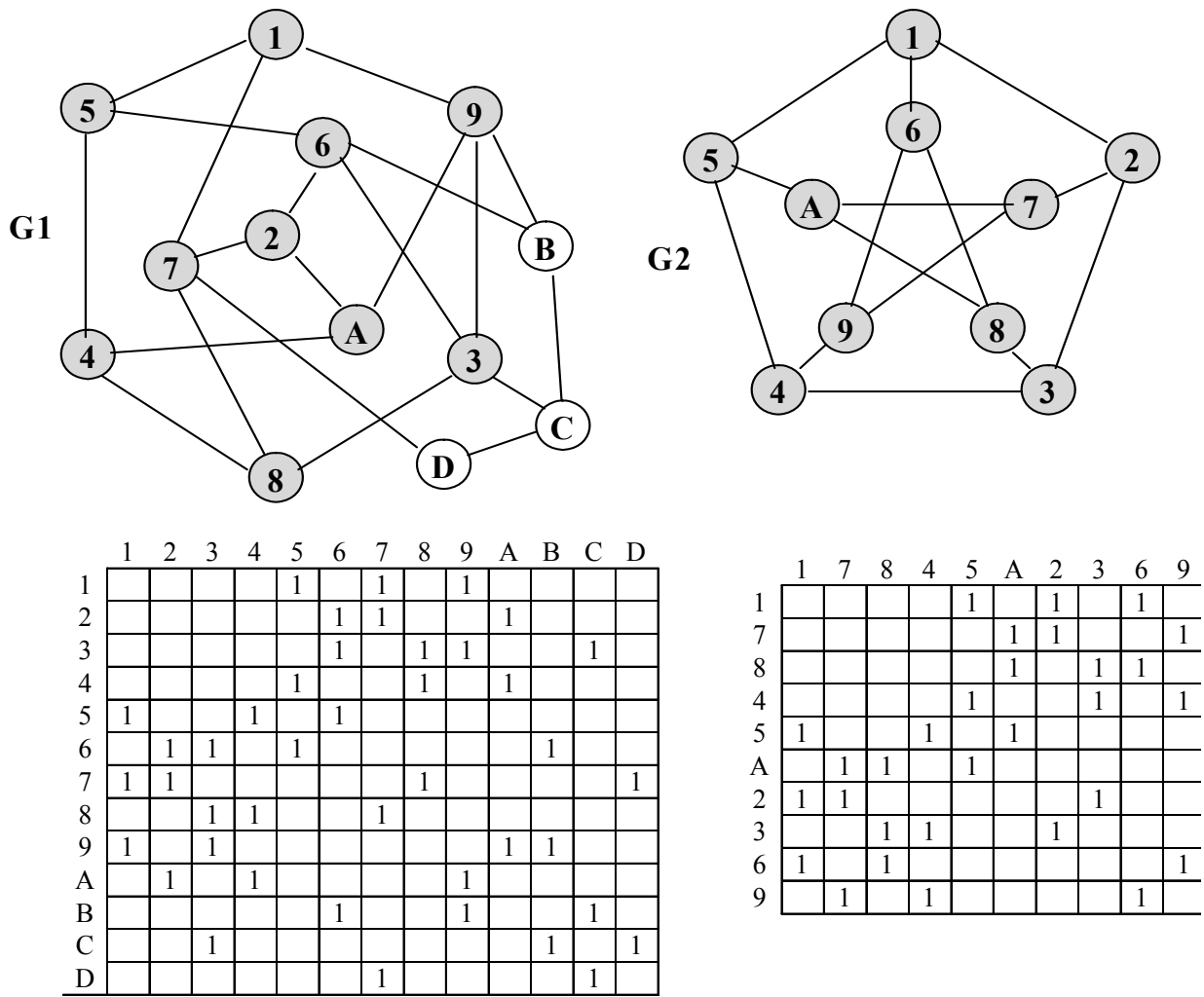

Fig. 3. An illustrative example of an isomorphic graph nesting

Рис. 3. Частный пример изоморфного вложения графов

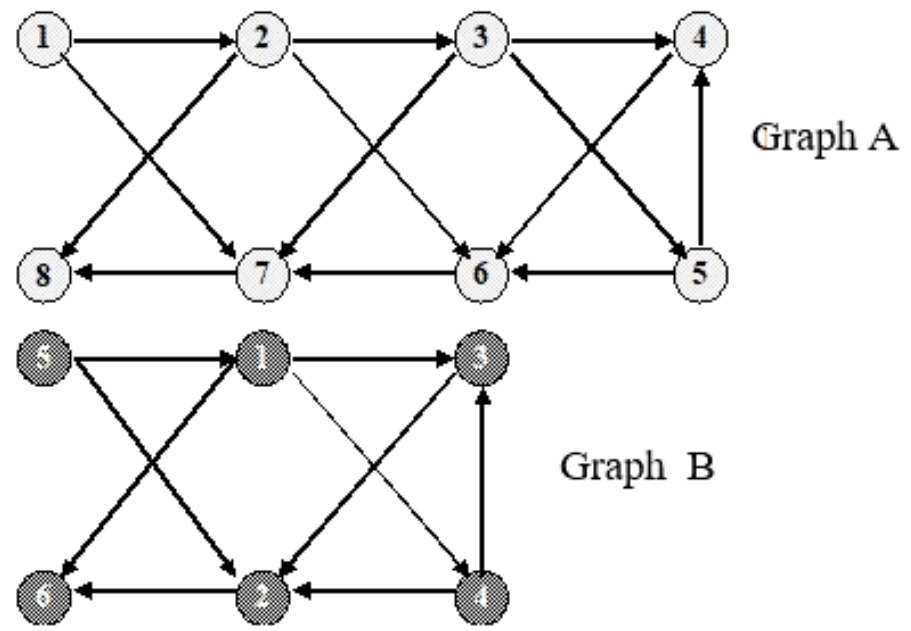

Fig. 4. Example of detection of a quality anomaly graph isomorphic nesting in SCLC configuration of IETM

Рис. 4. Пример распознания изоморфного вложения графа - аномалии качества на структуре ЛСПК ИЭТР 
Adjacency matrix of graph A:

\begin{tabular}{|c|c|c|c|c|c|c|c|c|c|}
\hline & $\mathbf{1}$ & $\mathbf{2}$ & $\mathbf{3}$ & $\mathbf{4}$ & $\mathbf{5}$ & $\mathbf{6}$ & $\mathbf{7}$ & $\mathbf{8}$ & $\boldsymbol{S}^{-}(\boldsymbol{x})$ \\
\hline $\mathbf{1}$ & 0 & 1 & 0 & 0 & 0 & 0 & 1 & 0 & $\mathbf{2}$ \\
\hline $\mathbf{2}$ & 0 & 0 & 1 & 0 & 0 & 1 & 0 & 1 & $\mathbf{3}$ \\
\hline $\mathbf{3}$ & 0 & 0 & 0 & 1 & 1 & 0 & 1 & 0 & $\mathbf{3}$ \\
\hline $\mathbf{4}$ & 0 & 0 & 0 & 0 & 0 & 1 & 0 & 0 & $\mathbf{1}$ \\
\hline $\mathbf{5}$ & 0 & 0 & 0 & 1 & 0 & 1 & 0 & 0 & $\mathbf{2}$ \\
\hline $\mathbf{6}$ & 0 & 0 & 0 & 0 & 0 & 0 & 1 & 0 & $\mathbf{1}$ \\
\hline $\mathbf{7}$ & 0 & 0 & 0 & 0 & 0 & 0 & 0 & 1 & $\mathbf{1}$ \\
\hline $\mathbf{8}$ & 0 & 0 & 0 & 0 & 0 & 0 & 0 & 0 & $\mathbf{0}$ \\
\hline $\boldsymbol{S}^{+}(\boldsymbol{x})$ & $\mathbf{0}$ & $\mathbf{1}$ & $\mathbf{1}$ & $\mathbf{2}$ & $\mathbf{1}$ & $\mathbf{3}$ & $\mathbf{3}$ & $\mathbf{2}$ & \\
\hline
\end{tabular}

Adjacency matrix of graph B:

\begin{tabular}{|c|c|c|c|c|c|c|c|}
\hline & $\mathbf{1}$ & $\mathbf{2}$ & $\mathbf{3}$ & $\mathbf{4}$ & $\mathbf{5}$ & $\mathbf{6}$ & $\boldsymbol{S}^{-}(\boldsymbol{x})$ \\
\hline $\mathbf{1}$ & 0 & 0 & 1 & 1 & 0 & 1 & $\mathbf{3}$ \\
\hline $\mathbf{2}$ & 0 & 0 & 0 & 0 & 0 & 1 & $\mathbf{1}$ \\
\hline $\mathbf{3}$ & 0 & 1 & 0 & 0 & 0 & 0 & $\mathbf{1}$ \\
\hline $\mathbf{4}$ & 0 & 1 & 1 & 0 & 0 & 0 & $\mathbf{2}$ \\
\hline $\mathbf{5}$ & 1 & 1 & 0 & 0 & 0 & 0 & $\mathbf{2}$ \\
\hline $\mathbf{6}$ & 0 & 0 & 0 & 0 & 0 & 0 & $\mathbf{0}$ \\
\hline $\boldsymbol{S}^{+}(\boldsymbol{x})$ & $\mathbf{1}$ & $\mathbf{3}$ & $\mathbf{2}$ & $\mathbf{1}$ & $\mathbf{0}$ & $\mathbf{2}$ & \\
\hline
\end{tabular}

Possible permutations matrix (matrix C):

\begin{tabular}{|c|c|c|c|c|c|c|c|c|c|}
\hline & A1 & A2 & A3 & A4 & A5 & A6 & A7 & A8 & $\begin{array}{c}\text { Number of } \\
\text { permutations }\end{array}$ \\
\hline B1 & 0 & 1 & 1 & 0 & 0 & 0 & 0 & 0 & $\mathbf{2}$ \\
\hline B2 & 0 & 0 & 0 & 0 & 0 & 1 & 1 & 0 & $\mathbf{2}$ \\
\hline B3 & 0 & 0 & 0 & 1 & 0 & 1 & 1 & 0 & $\mathbf{3}$ \\
\hline B4 & 0 & 1 & 1 & 0 & 1 & 0 & 0 & 0 & $\mathbf{3}$ \\
\hline B5 & 1 & 1 & 1 & 0 & 1 & 0 & 0 & 0 & $\mathbf{4}$ \\
\hline B6 & 0 & 0 & 0 & 1 & 0 & 1 & 1 & 1 & $\mathbf{4}$ \\
\hline
\end{tabular}

Fig. 5. Adjacency matrices of graphs and of possible permutations

Рис. 5. Матрицы смежности графов и возможных подстановок

And the first of the previously unused cells of the corresponding string is assigned the so-called "focus", i. e. an active cell is set (the coordinates of permutation vertices $C[$ FocB, FocA $]$ are determined). The remaining ' 1 ' characters must be "covered" by Mirage variable.

When $B_{i} \leftrightarrow A_{j}$, to the vertices $B k(k=1 \ldots m)$ adjacent to $B_{j}$, there can correspond only those $A l(l=1 \ldots n)$ vertices that are adjacent to $A_{i}$ vertex. To meet this condition, the so-called "extra" ' 1 ' characters in the possible permutations matrix must be "covered" by Mirage variable. Mathematically, this can be written as follows:

a) if $C[j, i]=$ ' 1 ' and $B[j, F O c B]=$ ' 1 ' and $A[j, F O C A] \neq$ $\neq$ ' 1 ' then $C[j, i]=$ Mirage;

b) if $C[j, i]=$ ' 1 ' and $B[F o c B, i]=$ ' 1 ' and $A[F o c A, i] \neq$ $\neq$ ' 1 ' then $C[j, i]=$ Mirage,

where $A, B$ are initial adjacency matrices, and $C$ is possible permutations matrix.
3. Other special constraints taking account of the specifics of detection of a quality anomaly graph isomorphically nested in a specified SCLC configuration within the IETM in operation.

The presented list of constraints is not complete and closed. In this case, the constraints perform the function of a logic filter. In accordance with the specifics of the problem of detection of a quality anomaly graph isomorphically nested in a specified SCLC configuration within the IETM in operation, additional filters - constraints may be introduced.

The proposed algorithm for detection of a quality anomaly graph isomorphically nested in SCLC configuration allows to specify the structure of quality anomaly detection method applied to IETM for aircraft maintenance and repair. The final version of the method structure is presented in fig. 6 


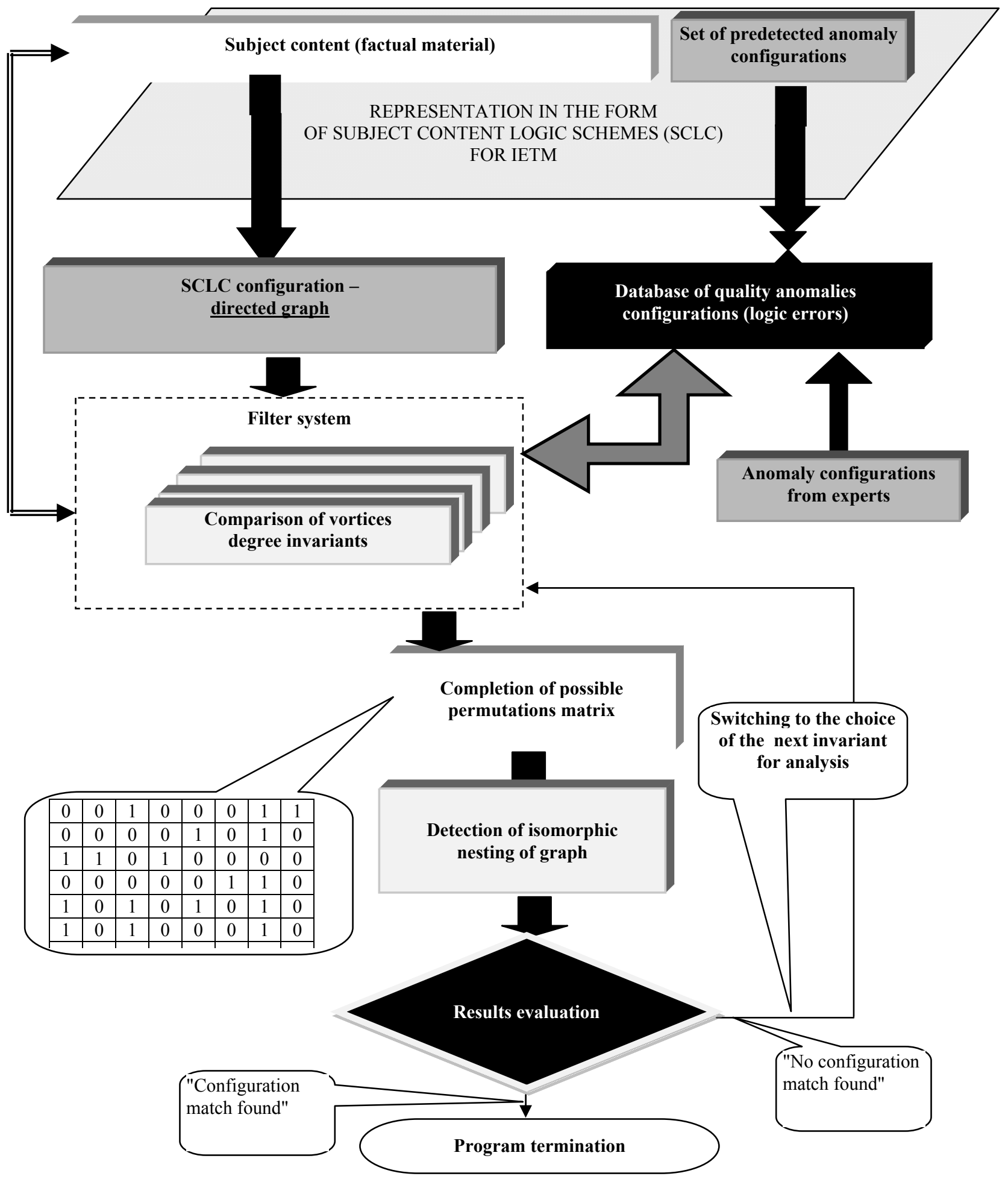

Fig. 6. Logic structure of method of detecting quality anomalies in IETM for aircraft maintenance and repair

Рис. 6. Логическая структура метода выявления аномалий качества ИЭТР по эксплуатации и ремонту авиационной техники

Generally, the method of quality anomalies detection of IETM for aircraft maintenance and repair comprises the following succession of key stages:

1) formalize and configurate SCLC for IETM in the form of directed graph;
2) select the configuration of the quality anomaly graph (logic error) from the database of quality anomaly configurations based both on the analysis of previously detected logic errors of content representation in IETM, and on relevant database provided by experts; 
3) using a filter system based on the selected pair of configuration models of SCLS proper and of the anomaly, complete the matrix of possible permutations;

4) solve the mathematico-logical problem of the graph isomorphic nesting detection;

5) analyze the detection outcome, if necessary, select for analysis the next version of configuration models of SCLS proper and of the anomaly.

Conclusion. The method of quality anomalies detection of IETM for aircraft maintenance and repair allows to detect logic-configuration anomalies of SCLC for IETR from the list (database) of pre-detected quality anomaly configurations (logic errors of electronic content presentation); the method can be applied to interpret the results of quality assessment of IETM for aircraft maintenance and repair, i.e. detection and elimination of the stated quality anomalies, the configuration of which is known in advance.

\section{References}

1. Bojcov B. V., Kryanev Y. V. [Implementation approach the concept of quality control. Theoretical and methodological aspectst]. Kachestvo i zhizn'. 2016, No. 4(12), P. 7-13 (In Russ.).

2. Boehm B. U. et al. Harakteristiki kachestva programmnogo obespecheniya [Characteristics of software quality]. Moscow, Mir Publ., 1981, 312 p.

3. Boehm, B. U. Inzhenernoe proektirovanie programmnogo obespecheniya [Engineering design software]. Moscow, Radio i svyaz' Publ., 1985, 252 p.

4. Bruks F. Mificheskiy cheloveko-mesyac ili kak sozdayutsya programmnye sistemy [Mythical man-month: how to create a software system]. Saint Petersburg, Simvol Publ., 2010, 304 p.

5. Boehm B. W. Software engineering economics. 1991 by Prentice-Hall, Inc., Englewood Cliffs, New Jersey 07632, USA. 767 p.

6. Frolova E. A et al. [The method of logical schemes of subject content to ensure the quality of the developed interactive electronic technical manuals]. Voprosy radioehlektroniki. 2018, No. 10, P. 58-65 (In Russ.).

7. Frolova E. A., Ivakin Ya. A. [Synthesis logical schemes of subject content maintenance and repair of aircraft equipment]. Informacionno-kommunikacionnye tekhnologii: dostizheniya, problemy, innovacii (IKT2018). Sb. st. I Mezhdunarodnoj nauchno-prakticheskoj konferencii [Information and communications technology: achievements, challenges, innovation (ICT-2018). Sat. article I of the International scientific-practical conference]. Polock, 2018, P. 224-226 (In Russ.).

8. Frolova E. A. et al. [Scientific-methodological concept of quality management interactive electronic technical manuals for operation and repair of aircraft]. Voprosy radioehlektroniki. 2018, No. 10, P. 66-74 (In Russ.).

9. Korshunov G. I. et al. The nature-technogenic control system design information maintenance. Proceedings of 2017 XX IEEE international conference on soft computing and measurements (SCM). 2017, P. 662-665.

10. Semenova E. G. et al. [Quality management of interactive electronic technical manuals for aircraft operation and maintenance at all stages of the life cycle].
Voprosy radioehlektroniki. 2018, No. 1, P. 73-81 (In Russ.).

11. Boem B. U. et al. Kharakteristiki kachestva programmnogo obespecheniya [Characteristics of the quality of software]. Moscow, Mir Publ., 1981, 312 p.

12. Frolova E. A. et al. [Formal representation of quality indicators of spatial processes management]. Conditions alternative to the development of modern economic systems management, innovation. Proceedings of the International scientific and practical conference. 2016, P. 182-192.

13. Frolova E. A., Ivakin Ya. A. [Quality anomaly of interactive electronic technical manuals for aircraft maintenance and repair]. Informacionno-kommunikacionnye tekhnologii: dostizheniya, problemy, innovacii (IKT2018). Sb. st. I Mezhdunarodnoy nauchno-prakticheskoy konferencii [Information and communication technologies: achievements, problems, innovations (ICT-2018). Sat. article I of the International scientific-practical conference]. Polock, 2018, P. 227-229 (In Russ.).

14. Zykov A. A. Osnovy teorii grafov [Fundamentals of graph theory]. Moscow, Vuzovskaya kniga Publ., 2004, 664 p.

15. Nechepurenko M. I. et al. Algoritmy $i$ programmy resheniya zadach na grafah $i$ setyah [Algorithms and programs for solving problems on graphs and networks]. Novosibirsk, Nauka Publ., 1990, 515 p.

\section{Библиографические ссылки}

1. Бойцов Б. В., Крянев Ю. В. Внедренческий подход в концепции качества управления. Теоретикометодологические аспекты // Качество и жизнь. 2016. № 4(12). С. 7-13.

2. Характеристики качества программного обеспечения / Б. У. Боэм [и др.]. М. : Мир, 1981. 312 с.

3. Боэм Б. У. Инженерное проектирование программного обеспечения : пер. с англ. М. : Радио и связь, 1985. $252 \mathrm{c}$.

4. Брукс Ф., Чапел Х. Мифический человекомесяц или как создаются программные системы. 2-е изд. СПб. : Символ, 2010. 304 с.

5. Boehm B. W. Software engineering economics / Prentice-Hall, Inc., Englewood Cliffs. New Jersey 07632, USA, $1991.767 \mathrm{p}$.

6. Метод логических схем предметного контента для обеспечения качества разрабатываемых интерактивных электронных технических руководств / Е. А. Фролова [и др.] // Вопросы радиоэлектроники. 2018. № 10. С. 58-65.

7. Фролова Е. А., Ивакин Я. А. Синтез логических схем предметного контента эксплуатации и ремонта авиационной техники // Информационно-коммуникационные технологии: достижения, проблемы, инновации (ИКТ-2018) : сб. ст. I Междунар. науч.-практ. конф., посвященной 50-летию Полоцкого государственного университета. Полоцк, 2018. С. 224-226.

8. Научно-методическая концепция менеджмента качества интерактивных электронных технических руководств по эксплуатации и ремонту авиационной техники / Е. А. Фролова [и др.] // Вопросы радиоэлектроники. 2018. № 10. С. 66-74. 
9. The nature-technogenic control system design information maintenance / R. I. Solnitsev [et al.] // Proceedings of 2017 XX IEEE Intern. Conf. on soft computing and measurements (SCM). 2017. P. 662-665.

10. Управление качеством интерактивных электронных технических руководств по эксплуатации и ремонту авиационной техники на всех этапах жизненного цикла / Е. Г. Семенова [и др.] // Вопросы радиоэлектроники. 2018. № 1. С. 73-81.

11. Характеристики качества программного обеспечения / Б. У. Боэм [и др.]. М. : Мир, 1981. $312 \mathrm{c}$.

12. Фролова Е. А., Мичурин С. В., Семенова Е. Г. Формальное представление показателей качества управления пространственными процессами // Conditions alternative to the development of modern economic systems management, innovation: Proceedings of the
International scientific and practical conference 2016 C. $182-192$.

13. Фролова Е. А., Ивакин Я. А. Модель аномалии качества интерактивных электронных технических руководств по эксплуатации и ремонту авиационной техники // Информационно-коммуникационные технологии: достижения, проблемы, инновации (ИКТ$2018)$ : сб. ст. I Междунар. науч.-практ. конф., посвященной 50-летию Полоцкого государственного университета. Полоцк, 2018. С. 227-229.

14. Зыков А. А. Основы теории графов. М. : Вузовская книга, 2004. 664 с.

15. Алгоритмы и программы решения задач на графах и сетях / М. И. Нечепуренко [и др.]. Новосибирск : Наука, 1990. 515 с.

(C) Frolova E. A., Ivakin Ya. A., Smirnov A. O., 2018 